A Carratalá (2016): "La información en prensa española sobre casos de violencia en parejas del mismo sexo". Revista Latina de Comunicación Social, 71, pp. 40 a 65.

\title{
La información en prensa española sobre casos de violencia en parejas del mismo sexo
}

\section{Press coverage of same-sex domestic violence cases in Spain}

\author{
A Carratalá [ $\underline{\mathrm{CV}}]$ [ $[\underline{\mathrm{ORCID}}]$ [GGS] Profesor Ayudante Doctor de Periodismo. Universitat de \\ València (España) adolfo.carratala@uv.es
}

\begin{abstract}
[ES] Introducción. Los medios de comunicación españoles se han hecho eco de diversos episodios de violencia en parejas del mismo sexo durante los últimos años. Dar cobertura a este fenómeno plantea interrogantes sobre cómo enfocar una realidad que se mantuvo oculta hasta hace muy poco. Metodología. El objetivo de este artículo es realizar un análisis de contenido de la información publicada en diversos diarios españoles entre 2010 y 2015. Resultados. Los resultados indican que, mientras que los periodistas han mejorado el tratamiento de la violencia de género, la información de las agresiones en parejas gays evidencia algunas características similares a las que dominaron las noticias sobre violencia contras las mujeres durante los primeros años. Conclusiones. Así, la cobertura episódica, el sensacionalismo y la descripción de los casos como crímenes pasionales señalan que la violencia intragénero no es abordada, por el momento, como un problema social sino más bien como un asunto privado.

[EN] Introduction. Spanish media have covered several cases of violence in same-sex couples in recent years. Reporting on this phenomenon raises questions about how to approach a reality that had remained hidden until recently. Method. The aim of this article is to analyse the content of the news stories about same-sex domestic violence published by various Spanish newspapers between 2010 and 2015. Results. The results indicate that, while journalists have improved the treatment of gender-based violence, the news coverage of violence in gay couples exhibits similar features to those that characterised the news coverage of violence against women during the early years. Conclusions. The episodic and sensationalist coverage, as well as the categorisation of cases of violence in same-sex couples as crimes of passion show that intra-gender violence is not addressed, for the time being, as a social problem but rather as a private matter.
\end{abstract}




\section{Keywords}

[ES] noticias; prensa; violencia intragénero; homosexualidad; problemas sociales.

[EN] news; press; same-sex domestic violence; homosexuality; social problems.

\section{Contents}

[ES] 1. Introducción. 2. Género y violencia: la respuesta periodística. 2.1. La cobertura de la violencia de género. 2.2. Violencia en parejas del mismo sexo: cómo conceptualizarla, cómo narrarla. 3. La (in)visibilidad de gays y lesbianas en el relato mediático. 4. Planteamiento del estudio. 4.1. Objetivos e hipótesis. 4.2. Corpus y metodología. 5. Resultados. 5.1. Presentación y jerarquización de las noticias. 5.2. Empleo de imágenes. 5.3. Información e interpretación. 5.4. Fuentes empleadas. 5.5. Motivos del crimen: móvil y responsabilidad del homicida. 5.6. Sensacionalismo. 5.7. Empleo de eufemismos y estereotipos. 5.8. Categorización del suceso. 5.9. Equiparación con otros tipos de violencia. 5.10. Tematización. 5.11. Recursos de ayuda. 6. Discusión y conclusiones. 7. Bibliografía.

[EN] 1. Introduction. 2. Gender and violence: the journalistic response. 21. Coverage of genderbased violence. 2.2. Violence in same-sex couples: how to conceptualise it and present it. 3 . (In)visibility of gays and lesbians in the media narrative. 4. Approach of the study. 4.1. Objectives and hypotheses. 4.2. Research body and methods. 5. Results. 5.1. Presentation and hierarchy of news. 5.2. Use of images. 5.3. Information and interpretation. 5.4. Sources employed. 5.5. Motives for the crime: motive and responsibility of the murderer. 5.6. Sensationalism. 5.7. Use of euphemisms and stereotypes. 5.8. Categorisation of the events. 5.9. Equalisation to other types of violence. 5.10. Thematisation. 5.11. Support resources. 6. Discussion and conclusions. 7. References.

Traducción de CA Martínez-Arcos (Doctor en Comunicación por la Universidad de Londres)

\section{Introducción}

Los medios de comunicación españoles han informado sobre diversos episodios de violencia en parejas del mismo sexo durante los últimos años. El fenómeno no había sido objeto de atención pública hasta entonces, debido a la invisibilidad que la comunidad LGTB (lesbianas, gays, transexuales y bisexuales) ha sufrido tradicionalmente. La cobertura de estos casos ha situado a los periodistas ante una nueva situación y, por lo tanto, ante la necesidad de articular un relato con el que otorgar sentido a esta realidad. El desafío implica, entre otras cuestiones, la definición y categorización de los hechos.

Paralelamente, las organizaciones que trabajan por la defensa de los derechos de las personas homosexuales también han realizado manifestaciones públicas en torno a estos sucesos, que mayoritariamente califican como violencia intragénero. Sin embargo, sus mensajes muestran cierta discordancia sobre cómo categorizar esta violencia y sobre cómo debe plantearse el discurso público en torno a ella. Mientras algunos colectivos estiman que la violencia que se da en las parejas homosexuales ha de ser considerada violencia de género, otras organizaciones defienden que estas agresiones son un fenómeno diferente al que sufren las mujeres heterosexuales a manos de sus parejas varones. 
Asimismo, estas voces revelan divergencias sobre cuál debe ser la respuesta que la política y la sociedad han de dar a estas situaciones. Parcialmente por ello, las instituciones tampoco han ofrecido una propuesta clara con la que abordar el problema, constatándose la falta de un planteamiento integral desde la administración pública. Ante este complejo escenario en el que se enmarcan los primeros debates sobre el fenómeno, es preciso conocer cuál es la aportación periodística a la discusión mediante el análisis del tipo de cobertura que los medios ofrecen sobre esta realidad.

\section{Género y violencia: la respuesta periodística}

\subsection{La cobertura de la violencia de género}

La violencia ejercida contra las mujeres ha ido ganando más y más espacio en los medios de comunicación desde la década de los 70 (Berganza, 2003). El tratamiento periodístico que el fenómeno ha recibido a lo largo de este tiempo ha ido evolucionando hasta alcanzar un registro que refleja la seria consideración que el problema ha despertado en sociedad e instituciones. La mejora de la cobertura periodística de este fenómeno se debe a un conjunto de factores que demuestran la creciente sensibilización del conjunto de la sociedad en torno a la violencia machista. En primer lugar, es preciso destacar la acción colectiva desplegada por las organizaciones feministas comprometidas con la lucha contra la desigualdad que padecen las mujeres (Carballido, 2007).

También ha resultado clave la acción de los actores políticos, que a instancias de esos grupos organizados, han ido respondiendo progresivamente al fenómeno a través de diferentes actuaciones legislativas. Asimismo, no podemos obviar el esfuerzo de autorregulación que han llevado a cabo diversos medios de comunicación y organizaciones de periodistas, a menudo con el apoyo del mundo institucional y académico, con el objetivo de mejorar la cobertura que se elabora al informar sobre estos hechos.

Son diversos los conceptos que la prensa emplea para identificar esta violencia. Así, podemos encontrarnos con expresiones como violencia familiar, violencia contra la mujer, violencia machista, violencia sexista, violencia doméstica, crímenes de género, malos tratos, malos tratos en el ámbito doméstico, maltrato doméstico, terrorismo machista, terrorismo familiar o femicidio (Rodríguez, 2008: 174).

Sin embargo, la denominación más común es violencia de género, sobre todo desde la aprobación en 2004 de la Ley integral contra este fenómeno, pese a que dicho concepto se limite en la práctica a identificar realidades tradicionalmente catalogadas como violencia doméstica y deje fuera, así, otras relaciones de dominio del hombre sobre la mujer, como las que se dan en la violencia sexual o en el acoso en ámbitos laborales (Marugán, 2012).

De acuerdo con la Declaración sobre la eliminación de la violencia contra la mujer aprobada por la Asamblea General de las Naciones Unidas en diciembre de 1993, debemos entender por violencia de género:

"todo acto de violencia basado en el género que tiene como resultado posible o real un daño físico, sexual o psicológico, incluidas las amenazas, la coerción o la privación arbitraria de la libertad, ya sea que ocurra en la vida pública o en la privada." 
Precisamente también fue a partir de los 90 cuando el discurso mediático sobre la violencia que sufren las mujeres evidenció un giro de notable importancia, coincidiendo con la confirmación de que el cambio familiar que cuestionaba el modelo patriarcal tradicional y el consiguiente aumento de poder de negociación de las mujeres, acontecidos durante las últimas décadas del siglo XX, no habían supuesto una reducción del riesgo de maltrato machista (Meil, 2004).

Un episodio concreto, el del asesinato de Ana Orantes en 1997, es identificado a menudo como el punto de inflexión a partir del cual las noticias sobre esta violencia pasaron a verse influidas por otros procesos de selección, por un tratamiento informativo bien diferente y por una voluntad de sensibilización social y de ayuda a las posibles víctimas de estas agresiones (Berganza, 2003; VivesCases, 2005; Marín et al., 2011; Gámez, 2012).

Sin embargo, el proceso por el cual la violencia de género ha pasado a ocupar un espacio de interés público reconocido, contando para ello con el soporte de los medios de comunicación, no puede dividirse únicamente en dos periodos. Como bien han señalado diversos autores, la evolución que experimenta un determinado tema desde que se manifiesta hasta que se convierte en objeto de atención político-social recorre varias fases o etapas a lo largo de las cuales diversos actores y circunstancias deben ir concurriendo.

Downs (1972) identifica cinco diferentes etapas que constituirían el ciclo de atención de los problemas públicos: pre-problema (los medios muestran cierta indiferencia ante el asunto y, cuando lo abordan, favorecen los enfoques sensacionalistas o morales), descubrimiento alarmante del problema y entusiasmo eufórico (aumenta, y con rigor, la cobertura periodística y el asunto se percibe como una amenaza), toma de conciencia del coste que exige avanzar en su gestión (los medios favorecen la discusión sobre qué recursos y medidas es necesario poner en marcha para superar el problema), declive gradual de la intensidad del interés público y post-problema. La profesora Berganza señala que la violencia de género alcanzó la segunda etapa identificada por Downs a partir de 1997-1998 (2003).

Bosch y Ferrer prefieren observar la propuesta de Kitsuse y Spector sobre las fases que sigue el desarrollo de un problema social promovido por uno o varios grupos de individuos (2000: 10-11), distinguiendo así: la fase de agitación (un grupo de personas se esfuerza por reconvertir un problema privado en público y comienza a preparar acciones para buscar sus causas), la fase de legitimación y co-actuación (los principales agentes sociales e instituciones oficiales reconocen al grupo de presión y empiezan a actuar para atender sus deseos), fase de burocratización y reacción (la administración se hace cargo del problema y queda minimizado) y, por último, la reemergencia del movimiento (las políticas oficiales han generado tal descontento que los afectados por el problema se reactivan en busca de nuevas opciones).

Si observamos el fenómeno no desde la perspectiva de la acción colectiva sino desde el punto de vista de la acción mediática, podemos recurrir a los dos procesos señalados por Fagoaga (1994: 68): proceso de legitimación (los medios conceden noticiabilidad a algunos hechos por su adecuación a los valores-noticia y por ser facilitados por fuentes con suficiente autoridad) y el proceso de rutinización (consecuencia del anterior, los hechos ya han sido incorporados a la agenda mediática y cuentan con espacio habitual y personal dedicado a su cobertura). Ambas fases irían precedidas por una etapa conocida como proceso de determinación, en la que los movimientos sociales intentan crear nuevas prácticas significantes en torno a determinadas realidades con el objetivo de desambiguarlas. 
Los tres planteamientos estudiados hacen referencia, en definitiva, a la compleja dinámica que siguen los fenómenos desde que se dan en un plano alejado de la atención pública hasta pasar a ocupar un lugar clave en el espacio de discusión colectiva. Para que esa transformación sea posible, Hilgartner y Bosk consideran crucial acertar con la definición del problema y, por lo tanto, señalar qué aspectos de la realidad social no pueden continuar siendo tolerados tal y como se encuentran.

Esta tarea implicaría articularse en un espacio de discurso público e incluir un elemento perjudicial:

"A social problem is a putative condition or situation that (at least some) actors label a «problem» in the arenas of public discourse and action, defining it as harmful and framing its definition in particular ways" (Hilgartner y Bosk, 1988: 70).

Los medios se han revelado, por lo tanto, como una herramienta fundamental para el cambio cultural que ha permitido que, desde finales de los 90, la violencia de género sea considerada por la colectividad como un verdadero problema social (Carballido, 2007). A través de su mensaje, han permitido la articulación de un discurso público en contra de la violencia machista en el que esta es presentada como un ataque a los derechos humanos que afecta a la dignidad de todos los ciudadanos. Esta apuesta por abordar con una nueva mirada los hechos vinculados a este tipo de violencia fue implantándose gradualmente en las redacciones, como demuestran los análisis diacrónicos realizados con el objetivo de evaluar cómo ha evolucionado la cobertura periodística española en torno al fenómeno (Vives-Cases et al., 2005; Rodríguez, 2008; Marín et al., 2011).

Según han puesto de manifiesto las investigaciones desarrolladas sobre esta cuestión, la información periodística ha dejado de abordar estos crímenes como hechos puntuales recogidos en la crónica de sucesos para otorgarles, en cambio, un tratamiento que los visibilice como un problema de carácter social cuya erradicación debe preocupar a la colectividad en su conjunto. Las noticias sobre violencia machista se limitaron, durante una primera etapa, a identificar las agresiones sufridas por mujeres como crímenes pasionales (Rodríguez, 2008; Berganza, 2003), desarrollando una narración de los hechos en la que era habitual encontrar referencias a celos, enajenación mental, drogas, posesión, bajas pasiones, dominio y sentido de pertenencia... Elementos que, en definitiva, condenaban a la mujer y, en ocasiones, llegaban a justificar a los hombres violentos (Rodríguez, 2008: 173; Menéndez, 2014).

Como indican Vives-Cases et al., hasta 1998, la mayoría de las informaciones "se centraban en casos aislados, donde las mujeres aparecían sólo como víctimas o culpables de ser maltratadas, incluso justificaban o disculpaban la conducta violenta" (2005: 23). Era la aproximación episódica al fenómeno (Berganza, 2003), la presentación de la violencia contra las mujeres como un problema individual que favorecía la interpretación de que, por consiguiente, era consecuencia de circunstancias particulares.

Progresivamente, la violencia contra las mujeres dejó de ser enmarcada como manifestaciones puntuales descritas por medio de observaciones sensacionalistas y alusiones que bien podían interpretarse como atenuantes del crimen para poner en marcha una cobertura más amplia, elaborando noticias temáticas que evidenciaban una mayor preocupación por la contextualización del problema, los temas abordados y las fuentes empleadas. El hecho de que el fenómeno se integrara como una constante temática de los medios permitía su visibilización y su comprensión como un asunto de interés para la ciudadanía (Zurbano, 2010a). El discurso periodístico circunscribe así el fenómeno en el marco de las relaciones sociales basadas en las desigualdades de género (Vives- 
Cases et al., 2005: 23), facilitando herramientas de ayuda a las víctimas e informando de las sentencias que condenan a los delincuentes.

Pese a ello, algunas características continúan siendo mejorables, como el excesivo empleo de fuentes secundarias cuyas declaraciones poco aportan a la calidad de la información (Rodríguez, 2008: 183), la sobrerrepresentación de la violencia física con resultado de muerte frente a otras manifestaciones de violencia de género, la excesiva focalización en los aspectos policiales y judiciales mientras se invisibilizan las raíces del problema y se reifica a la mujer (Gámez, 2012; Gámez y Núñez, 2013), la falta de una mayor profundidad en la conceptualización del fenómeno (Zurbano, 2010b: 13), la necesidad de hacer un mayor esfuerzo en la pedagogía, la prevención y la reflexión (Menéndez, 2013) así como en la exposición de modelos alternativos o contramodelos tanto de mujeres como de hombres (Gómez, 2012).

\subsection{Violencia en parejas del mismo sexo: cómo conceptualizarla, cómo narrarla}

La violencia que se ejerce entre los miembros de una pareja del mismo sexo es, a menudo, denominada como violencia intragénero. De acuerdo con un estudio sobre el fenómeno elaborado por el colectivo Lambda, perteneciente a la Federación Estatal de Lesbianas, Gays, Transexuales y Bisexuales (FELGTB), para la Secretaría de Estado de Igualdad, del Ministerio de Sanidad, Política Social e Igualdad, esta forma de violencia presenta características parecidas, pero también rasgos diferentes, respecto a la violencia de género:

"Es un tipo de violencia familiar que se produce entre cónyuges, parejas, amantes, ex parejas del mismo sexo, con independencia de la duración de dicha relación, donde uno de los miembros de la pareja proporciona malos tratos (físicos, psicológicos, sexuales, etc.) a otro. No parece estar legitimada por un sistema ideológico o social como ocurre con la violencia de género y el patriarcado, pues no parece verosímil que una lesbiana maltrate a otra por ser lesbiana, sin embargo posee características similares a la violencia de género y otras específicas que señalaremos en el presente informe." (2011: 7-8).

El hecho de que este fenómeno muestre elementos que puedan vincularlo a la violencia de género ha motivado la aparición de un debate en torno a si estas agresiones deben conceptualizarse como tal, lo que implicaría que las medidas legislativas puestas en marcha durante los últimos años para proteger a las mujeres frente a la violencia machista amparasen también a las víctimas de violencia en parejas del mismo sexo. La controversia se da tanto a nivel activista como a nivel político-institucional. Los colectivos han manifestado sus discrepancias en torno a esta cuestión precisamente a partir de los últimos casos acontecidos en España. Mientras algunas entidades como la Federación Estatal de Lesbianas, Gays, Transexuales y Bisexuales (FELGTB) y el Colectivo de Gays, lesbianas, bisexuales y transexuales de Madrid (COGAM) consideran que los legisladores deberían poner en marcha una ley específica para estas parejas, otras organizaciones, como la Confederación de colectivos de lesbianas, gays, bisexuales y transexuales (COLEGAS), abogan por que la protección de estas víctimas se regule a partir de una modificación de la Ley integral contra la violencia de género de 2004 dado que, en su opinión, la violencia ejercida en el seno de parejas homosexuales presenta un "factor de género", poniendo así el acento en la construcción cultural y no en el sexo biológico de los individuos implicados. 
Esta divergencia de planteamientos se ve favorecida por la incongruencia que, en opinión de algunos especialistas (Coll-Planas et al., 2008), presenta la redacción de la Ley integral. Si bien es cierto que en su título incorpora el concepto violencia de género, en su desarrollo el texto tiene un claro "sesgo heterosexista" al centrarse en relaciones entre hombres y mujeres, "lo que deja de lado las situaciones de maltrato que pueda haber en relaciones de pareja de lesbianas o gays" al deducirse de esa redacción que "no se producen relaciones de género entre mujeres o entre hombres" (Ibíd.: 191).

En opinión de estos autores, un planteamiento que hubiese puesto el acento en los roles de dominante y subordinado podría estar más relacionado con una perspectiva de género, pues cabe entender este como un dispositivo cultural que determina relaciones de poder y desigualdad que, pese a apoyarse en el sexo, puede ir más allá. De este modo, voces como la de Sheila Jeffreys consideran que la mayoría de relaciones de lesbianas y gays siguen las mismas pautas que las heterosexuales al distribuir los roles de poder y desigualdad en la pareja (en Ibíd.: 192).

Voces activistas se manifiestan en la misma línea. Así, desde el colectivo vasco Aldarte afirman que al regularse el problema social que supone la violencia de género a través de la mencionada ley integral, los legisladores se han olvidado de las lesbianas y de los gays, dejando al colectivo en una "desprotección total" (Aldarte, s.f.). Para esta entidad, las razones por las que la violencia intragénero se da no tienen por qué ser necesariamente distintas a las razones por las que existe la llamada violencia machista, pues la ausencia de identificación con los roles socialmente establecidos no implica que no puedan desarrollarse determinadas actitudes de posesión en las parejas del mismo sexo.

Un punto de vista similar comparte Reina (2010), para quien la violencia entre los miembros de una pareja homosexual podría semejarse a las agresiones machistas contra las mujeres, pese a que también tendría unas características propias muy diferentes a la violencia de género. Así, en su opinión, en las parejas del mismo sexo, al igual que en las parejas heterosexuales, se establecen relaciones de poder. De tal modo, observaríamos que "uno de los dos miembros de la pareja es el que ejerce el poder sobre el otro" en función de aspectos como "ganar más dinero, ser mayor o menor que la pareja, tener más autoridad, pertenecer a una clase social superior, poder acceder a mayor cantidad de recursos o servicios materiales o sociales" (Reina, 2010: 35).

El debate se ha trasladado, como indicamos, a la esfera política. Así, desde algunas administraciones autonómicas, como la de Canarias o la de Extremadura, se ha planteado la posibilidad de reconocer la violencia que se da en el seno de parejas homosexuales como violencia de género en las normativas y leyes propias que tramitan en el ejercicio de sus competencias. No obstante, no es el objetivo de este trabajo resolver esta cuestión, ni siquiera reflejar la complejidad de posiciones y debates teóricos que pueden establecerse sobre la misma. El interés de nuestro estudio se fundamenta en la reciente trascendencia pública de diversos casos de violencia en parejas del mismo sexo, un fenómeno que ha entrado de manera puntual en los últimos años en la agenda mediática pero cuya incidencia real es, de momento, difícil de determinar.

De hecho, apenas existen datos o estadísticas sobre la prevalencia de este fenómeno. Las únicas dos fuentes que aportan cifras al respecto se corresponden con sendas iniciativas lanzadas por colectivos de defensa de la comunidad LGTB con la colaboración de instituciones públicas. Así, por un lado, se encuentra disponible el Informe de resultados del Estudio sobre Violencia Intragénero publicado por Aldarte en 2010. La campaña, que se inició dos años antes, consistió en la realización de una 
encuesta a través de Internet a 110 personas. Los participantes eran gays y lesbianas que sufrían o habían sufrido violencia de sus parejas, o bien, que conocían a alguien en esa situación.

Fue publicado el Informe sobre la situación de la violencia entre parejas del mismo sexo al que ya nos hemos referido. Este documento reconoce que los únicos datos existentes son los obtenidos por dos vías: la información directamente facilitada por los afectados que acuden a los programas locales de atención y las respuestas a encuestas realizadas a subgrupos específicos de la comunidad homosexual, como los jóvenes de entre 18 y 29 años y los gays seropositivos, que en cualquier caso no suponen muestras representativas dadas sus reducidas dimensiones. En opinión de Reina:

"El grado de violencia dentro de la comunidad LGBTQ (Lesbiana, Gay, Bisexual, Transgénero/Transexual y Queer) es difícil de determinar, debido a que existe un bajo nivel de investigaciones y, también, al hecho de que la casi totalidad, del personal técnico y entidades que trabajan con violencia intrafamiliar, está orientado a parejas heterosexuales, no sabiendo o no pudiendo, por tanto, este personal técnico dar respuesta a la víctima de una agresión en una pareja del mismo sexo. Sin embargo, se cree que el grado de violencia en parejas del mismo sexo es similar al que experimentan las mujeres en una relación heterosexual." (Reina, 2010: 34).

La escasez de datos parece apuntar, pese a todo, una clara conclusión: la violencia intragénero continúa en buena medida siendo un fenómeno invisible, encontrándose muy lejos de haber logrado la consideración de problema social. Por lo tanto, estos hechos no concentran de momento la atención de la esfera social y política como sí lo ha conseguido la violencia machista. De acuerdo con los colectivos, las agresiones sufridas en el seno de las parejas del mismo sexo permanecen en el anonimato porque quienes las padecen no lo manifiestan y a la sociedad y a los agentes sociales les cuesta creerlo, influidos por diversos mitos y estereotipos (Aldarte, s.f.). La incipiente presencia que esta violencia ha logrado hasta ahora en la arena mediática, cuyo análisis vertebra y justifica este trabajo, comienza a abrir al fenómeno las puertas de la discusión y consideración públicas.

\section{La (in)visibilidad de gays y lesbianas en el relato mediático}

La falta de visibilidad que, de acuerdo con los colectivos defensores de los derechos de la comunidad LGTB, sufre la violencia ejercida en parejas del mismo sexo resulta coherente con la dinámica de ocultación mediática tradicionalmente padecida por la comunidad homosexual. Esta escasa presencia de la realidad gay en el relato periodístico evidencia que la esfera pública conformada por los medios de comunicación ha encontrado dificultades en su tarea de actuar como puente entre la esfera privada, en la que son diversas las identidades que pueden entrar en juego, y la social, que privilegia claramente la heterosexual (Sampedro, 2008: 40).

Por este motivo, la invisibilidad, como una de las estrategias representativas más frecuentes cuando se trata de excluir todo lo que no encaja en el ideal de sociedad coherentemente estructurada (Gimeno, 2008: 72), se ha revelado como un recurso habitual del discurso periodístico que juega en contra de la naturalización de las orientaciones sexuales no normativas. En ocasiones, la ocultación es absoluta; otras veces, se juega con el empleo de eufemismos con tal de mantener una distancia aparentemente respetuosa con una realidad que el periodismo ha tardado en gestionar de manera conveniente, con precisión y rigor (Carratalá, 2011a). El resultado de ese enmascaramiento, más o 
menos absoluto, no es inocuo para la comunidad gay y lésbica, pues su no-representación puede conllevar graves efectos sobre sus vidas dado que, cuando un grupo de personas no existe en los medios de comunicación dominantes, no se discute sobre ellas, no se las critica ni tampoco son examinadas por el resto de la sociedad, incluyendo por quienes tienen la capacidad para tomar decisiones y gestionar políticas (De Jong, 2006: 39).

Coll-Planas indica que este ejercicio mediático se correspondería con los postulados del imperialismo cultural según el cual la aceptación de las personas homosexuales sólo se contemplaría como una acción razonable siempre y cuando estas mantengan su orientación sexual recluida en el ámbito privado. Por ello, esta práctica se ejecuta por medio del empleo de los estereotipos, la invisibilización, la inferiorización, la imposición de un imaginario social heterosexista y la homofobia liberal (2010: 103). De esta manera, el relato mediático configura y refuerza la construcción tanto de las representaciones hegemónicas como de las minoritarias.

Estas últimas incluyen las identidades sexuales alejadas de la heteronormatividad, de igual modo que a otras muchas minorías sociales. Unas y otras se ven, pues, afectadas al quedar arrinconadas en el relato periodístico o al ser incorporadas a él a partir de una serie de códigos que fortalecen y recuperan estereotipos, prejuicios y representaciones sesgadas. Según Taibi, "los grupos minoritarios o desfavorecidos son asociados con problemáticas y aspectos negativos" (2003: 36). Esos vínculos son los que nutren y dotan de vigor a las ideas que la mayoría de los individuos comparten sobre aquellas comunidades con las que su experiencia cotidiana puede no haberles puesto en contacto, pues todas las referencias que rodean a estas identidades en el discurso público funcionan como implicaciones ideológicas (Van Dijk, 2008).

Estas propuestas de lectura no han sido apenas cuestionadas durante mucho tiempo porque, precisamente, se alimentaban de las ideas y mitos culturalmente asumidos en torno a la homosexualidad. Por ello, tal y como ya indicaba Lippmann, "imaginamos la mayor parte de las cosas antes de experimentarlas [...] todas esas ideas preconcebidas gobernarán casi por completo nuestro proceso íntegro de percepción" (2003: 88), una acción favorecida por la llamada percepción humana selectiva (Rodrigo, 2000: 57), que nos empuja a centrar nuestra atención en aquellos aspectos de la realidad cuya evidencia ya teníamos interiorizada de antemano como parte incuestionable de la misma. La misma idea comparte Gomis, que afirma:

"El hecho se inserta a menudo en un marco ya previsto y preparado para él y como consecuencia se interpreta con las claves más a mano, que a veces son las del prejuicio. Se tiende a ver entonces en un hecho lo que se esperaba o se temía ver.” (Gomis, 1991: 69).

En efecto, tanto el prejuicio como el estereotipo constituyen dos de las herramientas que durante más tiempo han servido como fuente de control social al funcionar como dispositivos no neutrales que "han sido considerados como aquellas actitudes y opiniones previas que determinan nuestra interpretación acerca del otro" (Israel, 2006: 42). Su inclusión en el discurso mediático dificulta la tarea de interpretación precisa de la compleja realidad social inherente al ejercicio periodístico. Por ello, algunos autores reivindican la necesidad de poner en marcha prácticas comunicativas que dejen a un lado esos recursos que obstaculizan la explicación y la comprensión de las identidades minoritarias.

En opinión de Israel, la clave está en el llamado periodismo intercultural, aquel que se practica en la cobertura de "los acontecimientos en los que tienen un protagonismo informativo mujeres y grupos 
minoritarios" y que se caracteriza por la aproximación que hace a quienes son diferentes, por su capacidad por reconocer como iguales a los distintos, cuestionando la división entre "nosotros" y "ellos" que pone en riesgo el derecho a la diferencia (2000: 1).

\section{Planteamiento del estudio}

\subsection{Objetivos e hipótesis}

El objetivo principal de este trabajo es conocer cuáles son las características principales de la cobertura que la prensa española ha ofrecido sobre la violencia en parejas del mismo sexo a lo largo de cinco años a partir de la observación de algunos rasgos del discurso periodístico que pueden resultar significativos de acuerdo con los resultados obtenidos en el examen del tratamiento periodístico de la violencia de género, que, como hemos visto, cuenta con una mayor tradición académica, y de las pautas de representación habituales de la comunidad homosexual, también señaladas en el marco teórico del trabajo. Este objetivo nos obliga a centrar nuestra atención en el tipo de enfoque que la prensa ha ofrecido sobre este fenómeno, identificando los atributos con los que aparece asociado.

El estudio de ese marco, según De Vreese, nos permite fijar la atención no tanto en la notabilidad del asunto sino en el modo en que es presentado, observando así los aspectos que sobre este tema gozan de mayor énfasis o relevancia (2005: 53). El subrayado de esos elementos y las relaciones que se establezcan entre ellos permiten a los medios construir una narrativa que incorpore, entre otras cuestiones, la definición del problema abordado y el análisis de sus causas (Entman, 2007: 164). Por lo tanto, se trata de conocer qué tipo de lectura sobre la violencia intragénero facilitan los medios de comunicación españoles, pues es a través de esa función interpretativa como el periodismo es capaz de problematizar la realidad; esto es, de definir y enmarcar todo aquello que está en juego en la sociedad (Neveu, 2004: 84).

Dada la falta de visibilidad que este fenómeno tiene en la sociedad española, según afirman quienes han realizado las primeras aproximaciones analíticas al mismo, consideramos que la información periodística disponible estará lejos de presentarlo como un problema social que merezca ser objeto de atención pública. Por lo tanto, nuestra hipótesis de partida es que el tratamiento informativo de la violencia en parejas del mismo sexo mostrará rasgos similares a los que caracterizaron la cobertura sobre violencia de género durante una primera etapa, hasta finales de los años 90, además de particularidades propias del discurso periodístico sobre las orientaciones sexuales minoritarias, tradicionalmente construido sobre prejuicios y estereotipos.

\section{Corpus y metodología}

Para el desarrollo de este análisis, se ha sometido a estudio la cobertura periodística que la prensa española ha realizado sobre los casos de violencia en parejas del mismo sexo conocidos entre el 1 de enero de 2010 y el 31 de diciembre de 2014 y que ha sido posible identificar mediante una búsqueda avanzada a través de la herramienta en línea MyNews, una base de datos de prensa que almacena las ediciones de los principales periódicos españoles desde 1996, sumando en total más de 200 periódicos y 800 fuentes online. La exploración de esos cinco años dio como resultado 
informaciones referidas a cuatro episodios de violencia en parejas homosexuales. En todos los casos, se trata de parejas gays y, además, también en todos los casos se trata de homicidios.

Para componer el corpus de unidades de análisis, se tomó la decisión de sumar todas las piezas vinculadas a los sucesos delimitados que fueron publicadas durante los tres días posteriores a la comisión del delito en las cuatro cabeceras de difusión estatal con redacción en Madrid. Ordenadas de más a menos lectores según los datos ofrecidos por el Estudio General de Medios (EGM), las cabeceras examinadas son El país (EP), El mundo (EM), Abc (Abc) y La razón (LR). Para esta investigación, se tomarán en consideración las ediciones locales que estos cuatro diarios publican en Madrid. Asimismo, se consideró pertinente incluir la cabecera regional más leída en aquellos episodios que hubieran tenido lugar en otras comunidades autónomas.

Los casos de estudio cuyo tratamiento informativo es sometido a análisis son:

El homicidio del joven R.C.C., de 30 años, en Xàbia (Alicante). Su novio lo apuñaló el 3 de julio de 2010. Se recogen las informaciones aparecidas entre el 4 y el 6 de ese mismo mes. Pese a que el diario regional más leído en Alicante es el Diario Información, no ha sido posible recuperar las noticias publicadas por esta cabecera, de tal modo que se incluye finalmente en el análisis la cobertura ofrecida por el segundo periódico regional más leído en la provincia, La verdad de Alicante (LV). En total, se obtienen 10 unidades de análisis.

Los tiros mortales recibidos por M.H., de 28 años, en Madrid. Le disparó su ex novio, que seguidamente se suicidó, el 26 de julio de 2011. Se realiza el seguimiento de la cobertura periodística publicada entre el 27 y 29 de ese mes. Se recogen 10 unidades de análisis.

El homicidio de M.A.A., de 40 años, en Madrid. El crimen lo perpetró su novio, que se suicidó tras cometer el delito. Los hechos tuvieron lugar el 20 de diciembre de 2011, pese a que no se descubrieron hasta el día siguiente. Por ello, se observan las ediciones publicadas entre el 22 y el 24 de ese mes. Tan solo se recuperan tres unidades de análisis.

El asesinato del actor K.L., de 54 años, en Bilbao. El marido de la víctima fue quien acabó con su vida. El suceso ocurrió el 19 de noviembre de 2014, pero el cadáver no fue hallado hasta el día siguiente. La revisión hemerográfica se realiza observando las informaciones publicadas entre el 21 y el 23 de ese mes. Además de los cuatro diarios estatales examinados, en este caso se suma la cabecera El Correo Español-El Pueblo Vasco (EC). La búsqueda suma 12 unidades de análisis.

En total, pues, el corpus se compone de 35 piezas redaccionales sobre las que se llevará a cabo un análisis de contenido. De acuerdo con la tradicional definición aportada por Berelson (1971: 18), esta técnica nos facilita el estudio del contenido manifiesto de los mensajes a través de una descripción objetiva, sistemática y cuantitativa. También Bardin señala que el análisis de contenido consiste en "un conjunto de técnicas de análisis de comunicaciones tendente a obtener indicadores (cuantitativos o no) por procedimientos sistemáticos y objetivos de descripción del contenido de los mensajes" (1986: 32).

Nuestra aproximación al corpus será fundamentalmente cuantitativa, con el objetivo de identificar y contabilizar la presencia de características específicas o dimensiones de los documentos y, con ello, ser capaces de obtener información sobre los mensajes, imágenes y representaciones vinculados con esas piezas y sobre su significancia social desde un punto de vista más amplio (Hansen et al., 1998). Las ventajas de esta apuesta metodológica han sido subrayadas por numerosos científicos sociales, 
que destacan el alto grado de rigor, precisión y fiabilidad que su utilización aporta a los datos resultantes al someter los mensajes a categorías explícitamente identificadas (Deacon et al., 1999: 133).

Para ello, hemos elaborado una hoja de codificación que se compone de 11 diferentes categorías que abordan distintos aspectos vinculados con el enmarcado de la cobertura, como la presentación visual de la información, las fuentes empleadas o los móviles del crimen señalados, entre otros. No obstante, conscientes de las limitaciones de esta técnica cuando el número de unidades a examinar es escaso, también exploraremos algunos aspectos de la cobertura analizada desde una perspectiva más cualitativa, vinculados a las opciones discursivas más significativas, y que permitan ilustrar e interpretar algunos de los datos que el examen cuantitativo ponga de manifiesto.

Así, por ejemplo, el trabajo examina críticamente el empleo de eufemismos (Carratalá, 2011a) y también las implicaciones ideológicas (Van Dijk, 2008) que pueden desprenderse de la inclusión de determinados estereotipos, de la categorización que se hace de los hechos narrados y de la motivación del homicidio al que apuntan las informaciones. Las 11 variables tomadas en consideración durante el procedimiento de análisis han sido elaboradas a partir de la revisión bibliografía efectuada y, por lo tanto, recogen las categorías que los estudios realizados hasta el momento han demostrado más significativas en la investigación sobre la cobertura mediática tanto de la violencia de género como de la comunidad LGTB:

1) Presentación y jerarquización de las noticias. La valoración del espacio otorgado a las piezas, si por ejemplo se encuentran en una ubicación privilegiada o no dentro del medio (portada, página par/impar...), se ha demostrado relevante en diversos trabajos anteriores sobre cómo la prensa aborda la violencia machista (Marín et al., 2011; Zurbano, 2012).

2) Empleo de imágenes. En investigaciones previas (Marín et al., 2011), el análisis de la presencia o no de acompañamiento gráfico y el contenido del mismo (agresor, cadáver, vecinos, localización...) se ha revelado como un aspecto significativo del tratamiento informativo de la violencia de género. Asimismo, algunos códigos y manuales deontológicos, como el elaborado por el Instituto de la Mujer y por profesionales de RTVE en 2002, recogido por Rodríguez (2008), también hacen referencia a cuestiones relacionadas con ello, como es la necesidad de respetar la dignidad de la víctima mientras sí se acepta identificar la figura del agresor.

3) Información e interpretación. La necesidad de ir más allá de la simple descripción de los hechos e intentar contextualizar y aportar datos constituye un factor clave en la cobertura de este fenómeno, tal como se ha señalado en análisis precedentes (Marín et al., 2011). De acuerdo con Berganza (2003), "la explicación del contexto en el que se producen este tipo de delitos adquiere una gran importancia a la hora de la definición y reconocimiento social del problema".

4) Fuentes empleadas. El estudio de qué actores son incorporados como fuentes en la construcción de la información sobre violencia de género se ha demostrado muy útil para evaluar si la cobertura se plantea como una noticia de sucesos o como problema social (Berganza, 2003; Vives-Cases et al., 2005; Marín et al., 2011). Asimismo, el análisis de este indicador también se ha considerado de interés en la investigación sobre cómo el periodismo aborda noticias vinculadas con la realidad LGTB (Carratalá, 2011b). 
5) Motivos del crimen: móvil y responsabilidad del homicida. Algunas de las investigaciones realizadas hasta el momento sobre cómo el periodismo aborda la violencia de género han alertado del peligro que supone introducir algunos atenuantes en la narración de los hechos que puedan presentar al agresor como un enfermo (Marín et al. 2011). Asimismo, determinados manuales de estilo, como el del Instituto Andaluz de la Mujer, subrayan que no debe exponerse la agresión como si fuera una consecuencia lógica de la pasión amorosa de algunos sujetos. Según señala Rodríguez (2008) en su estudio, deben evitarse calificativos atribuidos al asesino como celoso, bebedor o enfermo mental para así no frivolizar, minimizar o distorsionar la noticia desviando la atención de las verdaderas causas.

6) Sensacionalismo. De acuerdo con Berganza (2003), uno de los riesgos de la contextualización de esta realidad es la representación de la violencia como espectáculo, lo que supone una recreación sensacionalista centrada en la descripción de detalles y elementos morbosos. También otros estudios (Marín et al., 2011) analizan hasta qué punto el periodismo pone el acento en los pormenores y se acerca al amarillismo cuando se trata de informar sobre violencia de género. La recomendación de huir del tratamiento sensacionalista queda recogida, además, en el manual de urgencia elaborado por el Instituto de la Mujer y RTVE, donde se advierte del riesgo de confundir el morbo con el interés social y se pide no caer en el amarillismo (Rodríguez, 2008). Asimismo, el sensacionalismo ha sido un indicador examinado en coberturas periodísticas relacionadas con la comunidad LGTB (Carratalá, 2011b).

7) Empleo de eufemismos y estereotipos. Los eufemismos y los estereotipos son dos estrategias de representación identitaria habituales cuando la comunidad LGTB es objeto de información periodística, según se ha demostrado en investigaciones anteriores (Carratalá, 2011a; 2011b). Los estudios previos que han observado su presencia y el hecho de que algunos manuales de estilo sobre cómo cubrir la violencia de género expliciten la importancia de evitar su difusión (Rodríguez, 2008) justifica que sean incluidos como categoría de análisis.

8) Categorización del suceso. La mayoría de estudios desarrollados sobre el tratamiento informativo de la violencia de género han revelado la importancia de analizar qué terminología se emplea para aludir a una misma realidad (Rodríguez, 2008). Así, Berganza (2003) señala cómo, a finales de los 80 , los casos de malos tratos conyugales no se relacionaban con el marco en el que se suelen producir, desapareciendo así cualquier referente de la violencia de género en los textos. Otros trabajos también han fijado su atención en este asunto, subrayando la desigual presencia de conceptos como violencia de género, machista o contra la mujer (Marín et al., 2011) y reflexionando sobre el modo en que las formas de nombrar, caracterizar y representar los diferentes aspectos de la violencia de género influirá en la concepción de los públicos sobre qué es, cómo puede manifestarse y cuáles son los recursos a su alcance (Zurbano, 2010a).

9) Equiparación con otros tipos de violencia. Analizar si el fenómeno sobre el que se lleva a cabo la cobertura informativa es igualado a otras agresiones se demuestra de interés como señalan Rodríguez (2008), que identificó cómo algunos casos de violencia de género fueron equiparados al parricidio de manera incorrecta, o Zurbano (2012), que examinó hasta qué punto las diversas manifestaciones de violencia de género cubiertas por la prensa pueden quedar o no encuadradas de manera explícita bajo el concepto tal y como es empleado de manera habitual.

10) Tematización. La necesidad de examinar marcadores temáticos (Zurbano, 2012) en la información sobre violencia de género ha sido subrayada por diversas investigaciones previas, como 
la de Berganza (2003), que explica cómo en la década de los 90 se produjo el paso de noticias episódicas a noticias temáticas mediante la relación de unos hechos con otros y su presentación como una problemática social, o Vives-Cases et al. (2005), que subrayaron cómo la falta de un enfoque más multidimensional de la violencia de género ofrecía una versión simplificada del problema y de sus posibles soluciones.

11) Ayuda. La recomendación de ofrecer información útil, de servicio, durante la cobertura de agresiones de violencia de género es subrayada en algunos manuales, como el de RTVE (Rodríguez, 2008). Investigaciones previas (Zurbano, 2010b; Marín et al., 2011) han incluido en su análisis la identificación de la presencia de elementos de este tipo en las noticias que examinaron.

\section{Resultados}

En primer lugar, es necesario señalar que de las 35 piezas identificadas como pertinentes para nuestro estudio, dos no formarán parte del análisis cuantitativo diseñado para conocer las características del discurso informativo sobre la violencia intragénero al tratarse de dos artículos englobados en los llamados géneros de opinión (una columna y un editorial). De este modo, la codificación se ha realizado a partir del análisis de 33 unidades de carácter informativo.

Como ya se ha avanzado en el apartado metodológico, el caso de estudio que recibió una mayor cobertura fue el del homicidio de K.L., al contar con 12 piezas. Esta circunstancia podría explicarse, al menos en parte, por la notoriedad pública de la víctima, que había trabajado como actor en diversas ficciones audiovisuales. Respecto al medio de comunicación que en más ocasiones dedica espacio a informar sobre esta violencia, observamos que es el diario $A b c$ el que otorgó más atención a los cuatro sucesos examinados al publicar ocho piezas sobre los mismos, lo que le sitúa muy próximo del periódico El País, que sumó siete ítems en su cobertura de los crímenes seleccionados.

Las cabeceras regionales destacan, por otro lado, por ofrecer un mayor seguimiento a estas muertes, algo lógico si se tiene en cuenta que el factor noticioso de proximidad resulta mucho más relevante para estos medios. Así, La Verdad publicó tres piezas, durante tres jornadas consecutivas, sobre el homicidio registrado en Xàbia en 2010 (frente, por ejemplo, a $A b c$, que solo lo recogió el día posterior al suceso). El Correo difundió cinco piezas -más el editorial que no es codificado- sobre el crimen del actor en Bilbao ( $A b c$, sin embargo, únicamente dedicó una noticia a cubrir estos hechos).

\subsection{Presentación y jerarquización de las noticias}

Observamos que la mayor parte de las ocasiones las informaciones difundidas sobre violencia intragénero no cuentan con llamada en portada (73\%). En solo nueve casos, la noticia fue destacada en la primera plana del medio o en la portadilla interior que abre las páginas que componen la edición regional en el caso de los diarios estatales. Asimismo, el 61\% de las informaciones fueron ubicadas en página par, revelando así el dominio de este espacio, tradicionalmente considerado de menor importancia, frente a las planas impares. En relación a la extensión, la mayoría de unidades examinadas $(58 \%)$ se debaten entre ocupar $1 / 4$ y $1 / 2$ página. Una de cada tres piezas se extiende a lo largo de una o más páginas. 


\subsection{Empleo de imágenes}

La mayor parte de las unidades analizadas (76\%) cuentan con acompañamiento gráfico, que siempre, excepto en una ocasión, se trata de una fotografía. La víctima es el elemento principal de estas imágenes, que en numerosas ocasiones buscan identificarla mediante una foto reciente (28\%) o retratan el momento en el que se produce el levantamiento del cadáver (21\%). Como podemos observar en el gráfico, resulta menos habitual que el contenido gráfico identifique al agresor o que retrate el lugar del suceso o a los más allegados a los sujetos implicados en la noticia.

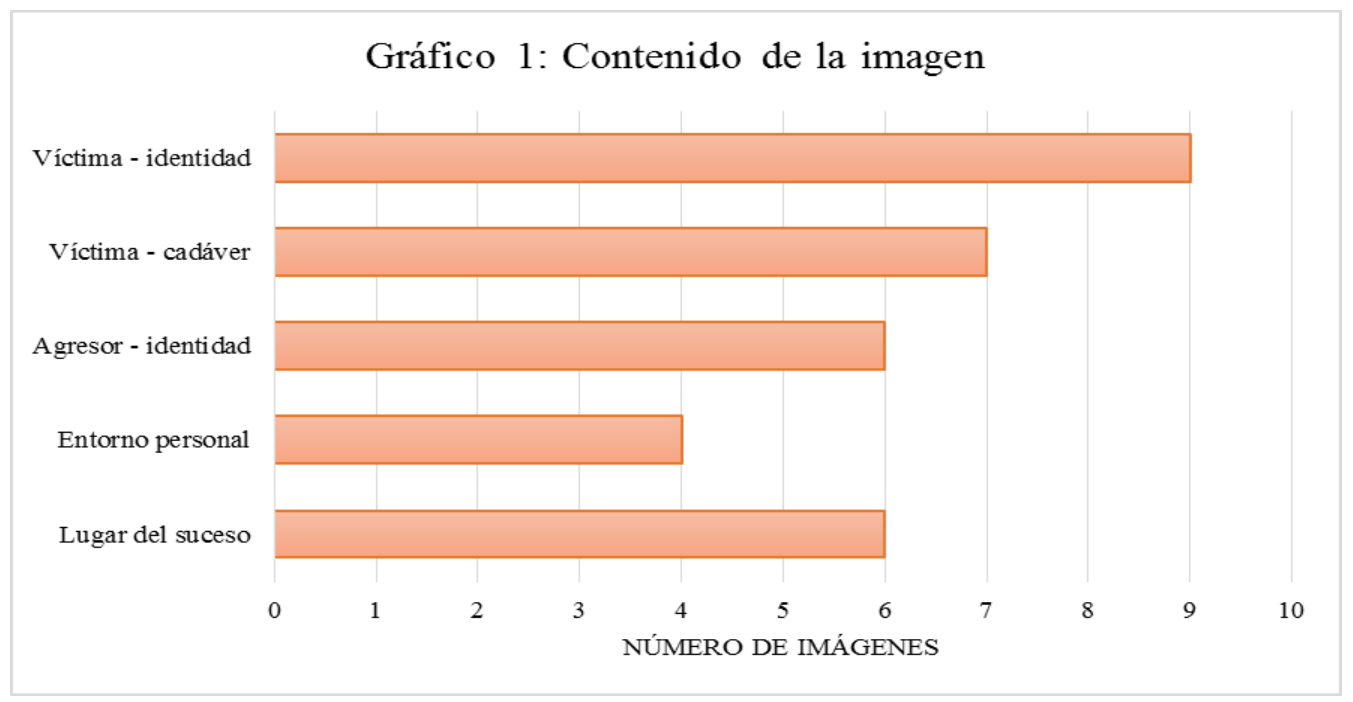

Fuente: elaboración propia.

\subsection{Información e interpretación}

La amplia mayoría de piezas (82\%) podrían ser consideradas propias del género genuinamente informativo, dado que se limitan a recoger datos e hipótesis sobre el crimen o declaraciones sobre el entorno próximo de la víctima y del homicida. Solo cuatro de las unidades codificadas se aproximan a relatos más interpretativos, cercanos a la crónica y al artículo-retrato de los implicados. Dado el predominio del discurso informativo, no sorprende que la mayoría de titulares $(52 \%)$ respondan también a este registro, siendo menor el número de casos en los que observamos titulares interpretativos/expresivos (33\%), como ocurre con "Pasión gay en el gym" (LR, 27/07/2011), o que recojan citas o declaraciones (15\%). Estos últimos se reservan para reproducir afirmaciones del entorno de la víctima, de los conocidos del agresor o, incluso, la declaración de este último: "El detenido en Xàbia dice que mató a su novio porque se durmió antes del sexo" (EM, 05/07/2010)

Muchas de las piezas informativas intentan, no obstante, aportar cierta contextualización de los hechos narrados, tanto sincrónica (observada en el 55\% de las informaciones) como diacrónica (más presente, hasta en el 76\% de los ítems, sobre todo al tratar de ofrecer un recorrido por la evolución de la pareja que protagoniza el hecho informativo). No obstante, en ambos casos nos referimos a la contextualización del suceso en sus circunstancias específicas, sin abordar su posible lectura como 
manifestación particular de un fenómeno violento de mayor alcance. Estos son dos ejemplos de cómo algunas informaciones tratan de interpretar la agresión específica a partir del historial sentimental de la pareja:

“...no existen denuncias anteriores por otros casos de violencia doméstica en el seno de la pareja" (LV, 06/07/2010)

"Fuentes de la investigación explicaron a $A b c$ que el funcionario acosaba constantemente a Marcos [...] Le llamaba por teléfono, iba a verle al trabajo..." $(A b c, 28 / 07 / 2011)$

\subsection{Fuentes empleadas}

En buena parte de las unidades de análisis detectamos fuentes vinculadas con el entorno personal de las personas implicadas: familiares, amigos, vecinos... Estas voces se recogen en más de la mitad de las informaciones (55\%). Es destacable el elevado número de casos en los que la información se presenta sin explicitar las fuentes que han proporcionado los datos o hipótesis reflejadas (42\%), bajo fórmulas como "fuentes próximas a la investigación". Sí se explicita que se ha consultado a fuentes policiales en un $30 \%$ de las informaciones examinadas. Sorprende la ínfima inclusión de fuentes oficiales del ámbito político, que aparecen en cuatro noticias; judiciales, solo citadas en dos ocasiones, y expertos, que tan solo observamos en una noticia en la que un criminólogo analiza el homicidio ocurrido en Bilbao. En ninguna de las informaciones se cita a fuentes vinculadas con las organizaciones de defensa de los derechos de la comunidad LGTB.

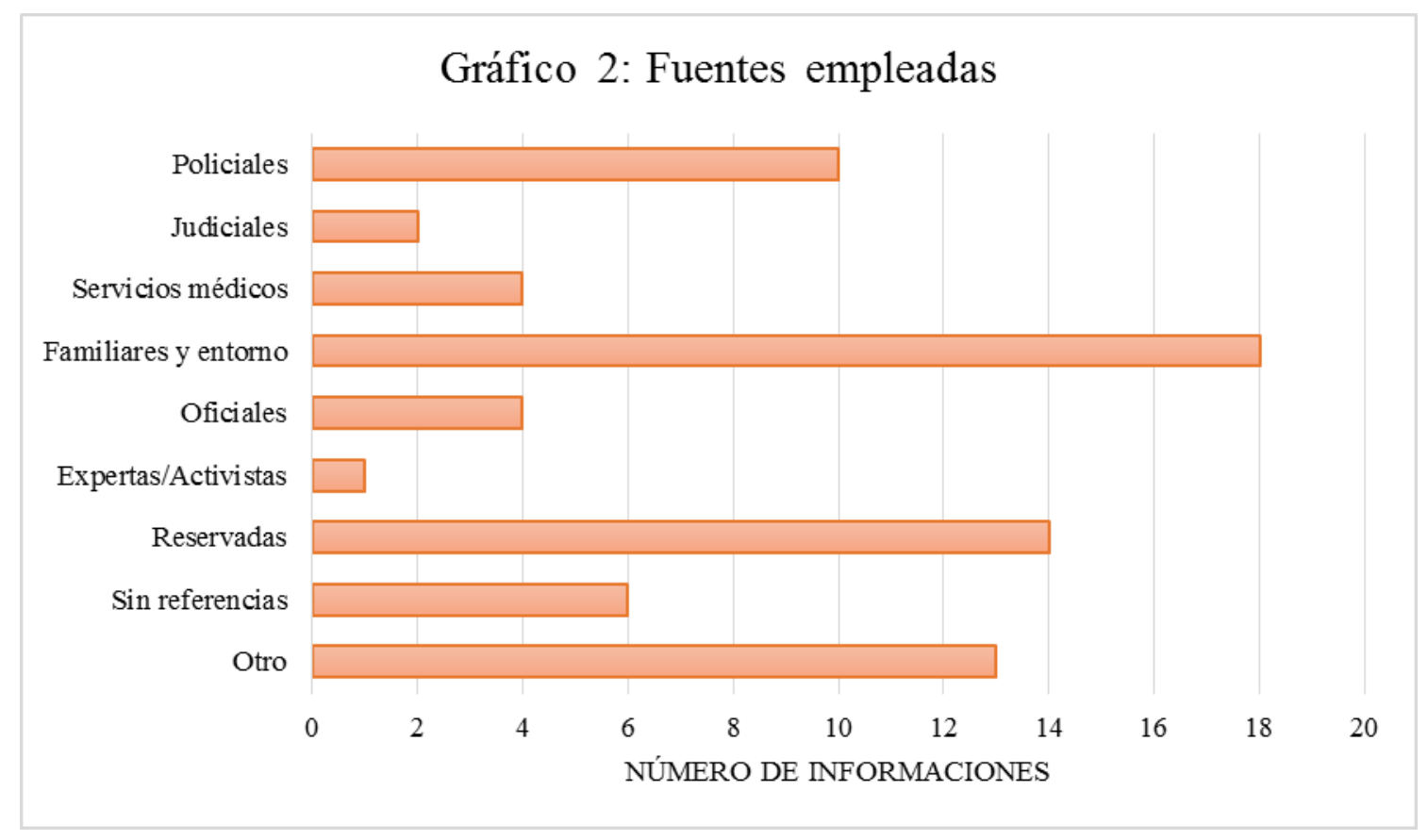

Fuente: elaboración propia.

El elevado empleo de fuentes de allegados a las personas que protagonizan la información -agresor y víctima- no se justifica por su relevancia en la construcción del discurso informativo. Los siguientes ejemplos muestran el escaso aporte periodístico que implica la introducción de estas voces en el 
relato explicativo de la actualidad, pues no pueden más que contribuir con vaguedades o ilustrar el dolor de los familiares:

"Los vecinos de la pareja explicaron que ninguno de los dos hombres eran conflictivos y afirmaron no haber escuchado la discusión tras la cual se produjo el crimen" ( $A b c$, 04/07/2010)

“«Se lo han llevado para siempre», «a ese lo mato yo, aunque me pase el resto de mi vida en la cárcel», eran las exclamaciones furiosas de los más cercanos a Rafael, un hombre muy discreto" $(L V, 04 / 07 / 2010)$.

“Según sus allegados, ambos eran buenas personas” (Abc, 27/07/2011)

“...según algunos clientes, su relación parecía «cordial»” $(L R, 27 / 07 / 2011)$

"Una comerciante [...] aseguraba ayer que Jon estuvo por allí la tarde del martes y que no le notó nada extraño, que le vio «hasta buen color»” $(E C, 21 / 11 / 2014)$.

\subsection{Motivos del crimen: móvil y responsabilidad del homicida}

El análisis revela que la gran mayoría de informaciones alude a los celos como posible móvil que explicaría la ejecución del crimen. Así ocurre en el 55\% de las piezas observadas.

Muchas veces esta causa se ubica en el mismo titular de la información, determinando desde el inicio el marco desde el que se aborda la noticia en su conjunto: "Un joven mata a su novio en Xàbia tras una discusión por celos" ( $L V, 04 / 07 / 2010)$, "El flirteo en una fiesta del orgullo gay desencadenó el crimen de Xàbia" ( $L V, 05 / 07 / 2010)$, "Los celos del sargento metódico" (EP, 28/07/2011), "El presunto asesino del actor Koldo Losada cometió el crimen por celos" (EP, 22/11/2014). El recurso a este móvil en la narración del crimen puede propiciar una explicación del mismo que sitúe al agresor como perjudicado por un estado de turbación generado por la víctima: “...confesó que un delirio se apoderó de su mente cuando vio que su pareja flirteaba con otros hombres en una velada homosexual celebrada en Valencia" ( $L V, 05 / 07 / 2010)$, "Ángel no pudo soportar que, en apenas medio año, Marcos ya estuviera con otro hombre" (LR, 27/07/2011). En otras ocasiones, la agresión se sitúa como el punto último de una discusión mantenida por homicida y víctima, una descripción que puede implicar cierto reparto de responsabilidad en la ejecución del crimen: "Ya por la tarde la gente los vio discutiendo en la puerta donde trabajaba la víctima" (EP, 27/07/2011), "Pasadas las cuatro de la tarde, y como consecuencia de una violenta discusión, presumiblemente por celos, el agente..." $(A b c, 27 / 07 / 2011)$.

Asimismo, aunque con menor frecuencia, encontramos menciones a la salud mental del agresor, una circunstancia que se indica en el $18 \%$ de las piezas, como ilustran estos ejemplos: “...el agresor sí recibía tratamiento médico por depresión” ( $L V, 04 / 07 / 2010)$, “...la Ertzaintza sospecha que el detenido pudo sufrir algún tipo de trastorno y actuar movido por celos enfermizos” (EC, 21/11/2014). Los móviles no son excluyentes en algunas de las unidades examinadas, siendo posible dar con noticias en las que son diversos los motivos que se indican para intentar explicar el suceso: “...al sargento se le cruzaron ayer los cables y el hecho de que siempre llevara dos armas encima hizo que una discusión al uso, mezclada con celos, acabara de la peor forma" $(L R, 27 / 07 / 2011)$. 


\section{Revista Latina de Comunicación Social \# 071 - Páginas 040 a 065 [Investigación] | DOI: 10.4185/RLCS-2016-1083| ISSN 1138-5820| | Año 2016}

No es habitual dar con afirmaciones que sugieran una clara descarga de responsabilidad por parte del autor del crimen, pero en tres unidades analizadas detectamos muestras de esta circunstancia. Así ocurre cuando se plantea un posible intercambio en la distribución de roles de víctima-agresor, como en el titular "«Marcos amenazó al sargento»" ( $L R, 28 / 07 / 2011)$, hecho que también se recoge en el desarrollo de otra pieza: “...Marcos había amenazado a Ángel Luis con que, si no le dejaba en paz, revelaría a todo su entorno su condición homosexual" ( $A b c, 28 / 07 / 2011)$, o cuando se pone en valor el supuesto cariño del homicida por la víctima, como vemos en este otro titular: " "Se le ha ido la cabeza, Koldo era el amor de su vida»" (EC, 22/11/2014). En el 36\% de las piezas no hallamos ninguna referencia al motivo que pudo desencadenar el crimen.

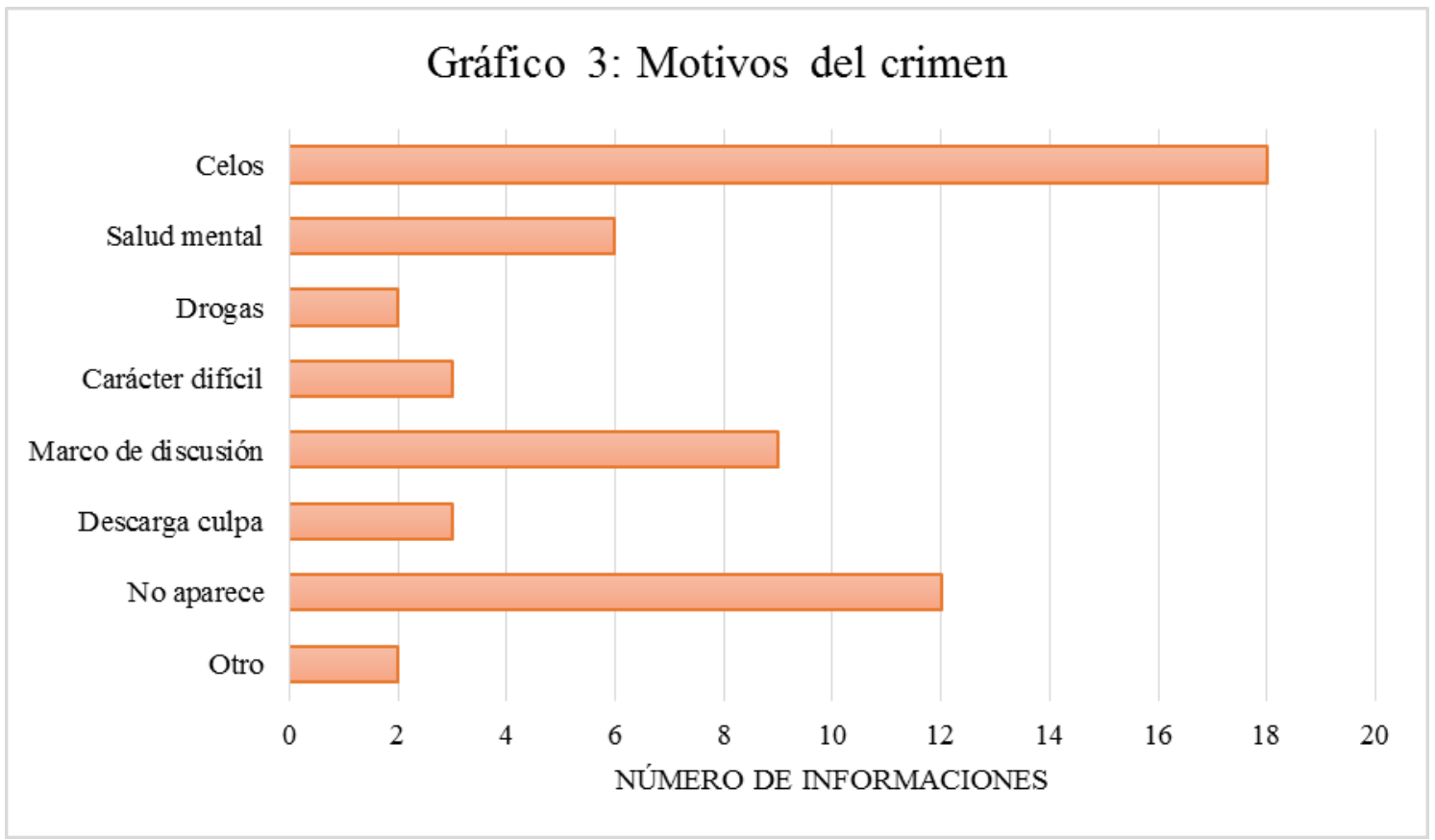

Fuente: elaboración propia.

\subsection{Sensacionalismo}

Algo más de la mitad de las informaciones analizas incluyen elementos sensacionalistas (52\%) en su desarrollo. Las 17 piezas en las que hemos detectado esta característica apuestan por la descripción de pormenores y detalles escabrosos, como podemos observar en los siguientes ejemplos, relacionados con los diferentes casos analizados:

"La rigidez del cadáver indicaba que el acuchillamiento mortal..." / "Los gritos de dolor despertaron a los vecinos" ( $L V, 05 / 07 / 2010)$

"Momentos de pánico" / "El guardia sangraba por la boca" (Abc, 27/07/2011)

"El travesti de Chueca degolló a hachazos a su novio tras romper" (Abc, 23/12/2011)

"...fue encontrado por la noche sin vida, tirado en el pasillo de la casa, con una toalla ensangrentada en la cabeza" $(A b c, 21 / 11 / 2014)$ 
Otras muestras evidencian voluntad sensacionalista al, por ejemplo, poner de relieve aquellos aspectos del hecho que mayor impacto o morbo pueden despertar al implicar cierto desajuste respecto a aquello socialmente asumido, como ocurre con las profesiones que suelen desempeñar los varones homosexuales. De este modo, cabe destacar dos titulares que subrayan la profesión del homicida, una circunstancia que probablemente no se habría destacado de no implicar la reacción mencionada: "Un guardia civil mata a su ex novio" (EM, 27/07/2011) y "Un bombero travestido mata a su novio" (EM, 22/12/2011). Por último, es preciso señalar la inclusión de una infografía que representa cómo fue ejecutado uno de los homicidios, con el dibujo de la víctima, del agresor, y de los puntos en los que impactaron las balas entre otros detalles ( $L R, 27 / 07 / 2011)$.

\subsection{Empleo de eufemismos y estereotipos}

Ocho de las informaciones analizadas (24\%) introducen alguna expresión eufemística en su redacción. El eufemismo más habitual es el que define a un miembro de la pareja homosexual habitualmente la víctima- como "compañero sentimental" del otro. En algunos casos, como en la noticia cuyo titular es "Detenido en Jávea tras matar a su compañero sentimental" ( $L R, 04 / 07 / 2010)$, esta es la única fórmula discursiva empleada para definir la relación entre los dos varones y se repite en dos ocasiones más, sin introducir posibles sinónimos. Otras veces, la expresión se combina con otras. Asimismo, es preciso señalar que resulta común encontrar términos alejados de cualquier voluntad eufemística, como novio, marido y pareja.

Aunque con menor frecuencia que los eufemismos, también identificamos el uso de algunas imágenes estereotipadas que acompañan al mundo gay. Ocurre así en siete de las informaciones analizadas (21\%). En ocasiones, estas representaciones aparecen junto con el móvil del delito que se desliza en la narración de los hechos, especulando sobre aspectos que sintonizan fácilmente con prejuicios como la promiscuidad de los varones homosexuales -“....según el detenido, los problemas empezaron porque el fallecido estuvo tonteando con otros jóvenes" (EM, 05/07/2010), "El flirteo en una fiesta del orgullo gay desencadenó el crimen de Xàbia" ( $L V, 05 / 07 / 2010)$ - o su elevado apetito sexual: "El detenido en Xàbia dice que mató a su novio porque se durmió antes del sexo" (EM, 05/07/2010). Otros ejemplos responden a imágenes aceptadas con cierta generalidad, como las que sitúan a los gays como hombres que cuidan excesivamente su imagen - "Marcos Hernández era un hombre que cuidaba mucho su cuerpo, pasada muchas horas en el gimnasio entrenándolo" ( $E P$, 27/07/2011) - o como varones que asumen un rol femenino/masculino cuando se encuentran en una relación sentimental -“Quienes le conocen desde niño sostienen que [...] «era el lado femenino de la pareja»" (EC, 22/11/2014)-. Asimismo, observamos estereotipos no exclusivamente ligados a la comunidad LGTB y que responden, en general, al mundo de las relaciones de pareja: “....aseguran que el hecho de que el sargento del Instituto Armando tuviera «varias propiedades» había «influido» en el amor que Marcos sentía por el guardia civil” (LR, 28/07/2011).

\subsection{Categorización del suceso}

Como podemos observar en el gráfico, son dos las categorizaciones más empleadas (18\%) para catalogar los homicidios que tienen lugar en el seno de una pareja del mismo sexo: violencia doméstica -“...procedieron al arresto de Ezkurdia, como presunto autor de un delito de violencia 
doméstica" (EM, 21/11/2014)- y crimen pasional. El empleo de este último concepto -ya prácticamente inexistente en el tratamiento periodístico de otros tipos de violencia- acostumbra a aparecer ligado a la mención de los celos como posible móvil del suceso y es identificado en piezas vinculadas a la cobertura de los diferentes casos: "En pocos segundos cruzó el umbral de los crímenes pasionales" ( $L V, 05 / 07 / 2010)$, "Al parecer, la víctima y el agente habían mantenido una relación sentimental que se rompió hace unos meses, por lo que todo apunta a un crimen pasional" $(A b c, 27 / 07 / 2011)$, o "La violencia de la agresión podría indicar que se trata de un crimen pasional" $(E C, 22 / 11 / 2014)$.

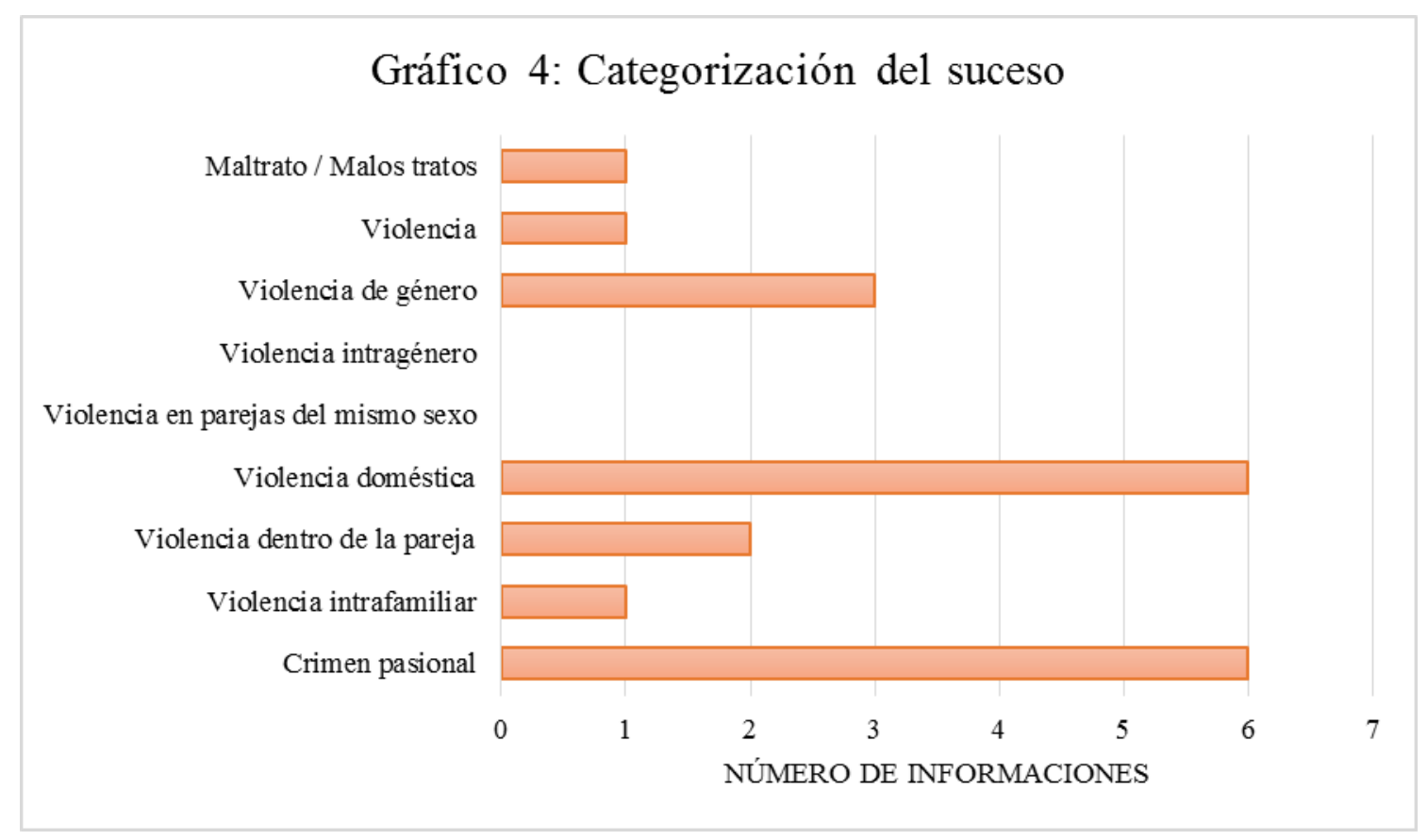

Fuente: elaboración propia.

En ocasiones, también se introducen otros conceptos vinculados a violencia doméstica, aunque implican matices que evidencian la dificultad para conceptualizar y categorizar con rigor el fenómeno al que nos referimos: violencia de género (9\%), violencia dentro de la pareja $(6 \%)$ o violencia intrafamiliar (3\%). Es significativo que ni una sola de las piezas considere estos casos como manifestaciones de violencia en parejas del mismo sexo o violencia intragénero, que son dos de los conceptos más empleados por quienes estudian estas agresiones desde el mundo asociativo o académico.

\subsection{Equiparación con otros tipos de violencia}

Tan solo en nueve de las piezas analizadas (27\%) encontramos referencias que permitan interpretar el hecho informativo como una manifestación más de un tipo de violencia general que puede sufrir cualquier pareja independientemente del sexo de sus miembros, más allá del nombre que se le atribuya al fenómeno. Así, observamos desde equiparaciones poco precisas en cuanto a su categorización _-...la historia de amor y desamor de esta pareja ha terminado, como la de tantas 
otras relaciones conflictivas, en el cementerio" ( $L R, 28 / 07 / 2011)$ - a otras más explícitas: "La violencia doméstica no entiende de sexos" $(A b c, 04 / 07 / 2010)$.

Algunos de los ítems exponen incluso lo que puede entenderse como una reivindicación, pues se defiende la equiparación sin distinciones de la violencia cometida en el interior de relaciones homosexuales con la que sufren las mujeres heterosexuales a manos de sus parejas machistas. En algunos casos, como producto de la inclusión de alguna fuente: "Los portavoces coincidieron en que este asesinato «constituye una expresión más de la falta de respeto y del abuso de poder que existe en muchas relaciones de pareja, sean homosexuales o heterosexuales»" (EC, 22/11/2014). En otros, es la propia voz del periodista quien reclama la necesidad de equiparar los distintos crímenes:

Mientras miles de gays celebraban ayer el día del Orgullo entre música y fiesta, en Xàbia un terrible suceso volvía a equiparar, por desgracia, a las parejas homosexuales con las heterosexuales. Y es que la violencia dentro de las relaciones sentimentales no entiende de géneros. Esta vez fueron dos hombres los que escenificaron en Xàbia la tragedia tantas veces contada, aunque con protagonistas diferentes $(E M, 04 / 07 / 2010)$.

También observamos otros ejemplos más sutiles en los que la equiparación se deduce al mencionar como antecedentes, tras el relato de lo ocurrido, casos de violencia machista: "En lo que va de año, tres mujeres han fallecido en la Comunitat Valenciana víctimas de violencia de género..." ( $L R$, 04/07/2010)

\subsection{Tematización}

Es muy extraño dar con perspectivas que abran el foco más allá del suceso particular sobre el que informan para abordarlo como un problema social de mayor complejidad. El $88 \%$ de las piezas codificadas se limitan a informar de lo ocurrido como un hecho episódico. Solo en cuatro ocasiones observamos cierto esfuerzo por tematizar el fenómeno, poniendo en relación el caso concreto con otros crímenes sucedidos. Una de estas propuestas opta por una tematización que tendría en cuenta únicamente la violencia ocurrida en el seno de parejas del mismo sexo: "Se trata del segundo crimen entre una pareja homosexual registrado en la provincia de Alicante. El primero sucedió en..." (EM, 04/07/2010). El resto de muestras apuestan, sin embargo, por abordar la presentación del caso como un ejemplo más de violencia de género: "Este crimen de violencia de género es el décimo en la Comunidad en lo que va de año..." (EM, 22/12/2011), “...se han multiplicado las muertes violentas. Diez mujeres han sido asesinadas por sus esposos..." (Abc, 22/12/2011).

\subsection{Ayuda}

Solamente en una de las piezas analizadas detectamos la inclusión de un elemento de servicio/ayuda que pueda orientar a personas que se encuentren en una situación similar. Se trata del servicio telefónico que acostumbra a indicarse en las informaciones sobre violencia de género: "(Teléfono 016 de atención a las víctimas de malos tratos)" (LR, 04/07/2010). 


\section{Discusión y conclusiones}

El análisis realizado sobre el tratamiento periodístico de estos cuatro casos de violencia intragénero nos permite identificar algunas características predominantes en el tipo de lectura que los medios de comunicación ofrecen en torno a esta realidad. Si bien es cierto que la interpretación de los resultados no puede generalizarse más allá de los hechos específicos observados, el examen sí nos ofrece suficientes evidencias para señalar que la cobertura en torno a estos sucesos presenta rasgos parecidos a los que investigaciones previas (Berganza, 2003; Vives-Cases et al., 2005; Rodríguez, 2008; Menéndez, 2014) han reconocido en el discurso periodístico sobre la violencia de género anterior a 1997: su presentación como crímenes pasionales o una narración de los hechos que disculpa al agresor. De este modo, podríamos señalar que la información que se elabora en torno a las agresiones en parejas del mismo sexo sitúa este problema lejos de ser considerado como objeto merecedor de atención política-social.

Siguiendo las etapas que, de acuerdo con Downs (1972), constituyen el ciclo de atención de los problemas públicos, los casos examinados ubicarían a la violencia intragénero en la fase de preproblema al encontrarnos con un enmarcado periodístico que le otorga escasa visibilidad (no aparece en portada, su emplazamiento se da en espacios menores y, sobre todo, en páginas pares) y que favorece los aspectos morbosos y sensacionalistas sin presentar las agresiones como indicadores de un problema que debiera generar cierta alarma o preocupación general. Diríamos, por ello, que la violencia en parejas del mismo sexo se aborda con estrategias informativas que hace 20 años eran habituales en el tratamiento de la violencia de género.

Este tipo de cobertura se explicaría por el hecho de que, como hemos visto, esta violencia no es equiparada mediáticamente a la de género en la mayor parte de los casos. Su presentación parece indicar que se trata de un fenómeno parecido, pero no igual. El hecho de que solo un $9 \%$ de las unidades de análisis emplease el concepto "violencia de género" para referirse a estas agresiones fórmula más frecuente cuando los medios abordan la violencia contras las mujeres (Rodríguez, 2008) - confirmaría el sesgo heterosexista que domina la expresión en sintonía con la formulación que se adoptó en la ley de 2004, tal y como han advertido algunos colectivos y académicos (CollPlanas et al., 2008). Pese a que esta preferencia por evitar la utilización del concepto "violencia de género" para identificar las agresiones que un varón gay puede recibir por parte de su pareja acercaría el discurso periodístico al de los colectivos LGTB que consideran que este fenómeno no es violencia machista, la falta de contacto con estas asociaciones podría explicar que la cobertura no favorezca un enmarcado de problemática social que avalase una de las demandas principales del mundo asociativo; esto es, una ley específica para proteger a los integrantes de estas parejas.

En efecto, la falta de reconocimiento de las organizaciones LGTB -que se deduce de su no incorporación como fuentes informativas- y los elementos que evidencian un enfoque episódico de esta violencia (presentes en el $88 \%$ de las unidades) pueden señalar que el fenómeno no ha superado las fases de agitación (Bosch y Ferrer, 2000) y de legitimación (Fagoaga, 1994). Esta evaluación de la cobertura periodística queda fundamentada si atendemos al enmarcado dominante de estos casos como noticias de sucesos y no como problema social, reproduciendo elementos que se han considerado negativos en el tratamiento mediático de la violencia de género de acuerdo con diversas investigaciones (Berganza, 2003; Vives-Cases et al., 2005; Marín et al., 2011) y códigos deontológicos (Rodríguez, 2008): imágenes de la víctima, falta de contextualización (con un enfoque informativo que se limita a describir el hecho y que, cuando lo explica, lo hace como caso singular y 
no como expresión de una violencia de mayores dimensiones), predominio de fuentes policiales y del entorno íntimo (sin incorporar a autoridades públicas o a expertos), ausencia de información de ayuda o servicios y empleo de expresiones que vinculan la agresión con una manifestación emocional/pasional y que presentan al agresor con ciertos atributos que pueden atenuar su responsabilidad en el crimen.

El paralelismo de este tipo de periodismo con el que dominó el tratamiento de la violencia de género antes de la muerte de Ana Orantes en 1997 (Gómez, 2012) nos exige preguntarnos si el paso de un enfoque episódico a otro temático podrá verse favorecido a partir de la cobertura de un caso insignia, que suponga un antes y un después debido a su impacto en la sociedad. En este sentido, el homicidio del varón de Bilbao parece reunir características que podrían otorgarle ese papel. La cobertura de este asesinato fue la que generó mayor número de unidades de análisis y la única que motivó la publicación de un editorial en uno de los periódicos analizados, lo que significa elevar el asunto a un tema de consideración y reflexión colectiva. Nuevas investigaciones que amplíen el análisis a futuro casos y a otros medios de comunicación (audiovisuales, digitales...) permitirían confirmar o no si este último homicidio impulsa un cambio en el modo de cubrir esta realidad.

Aunque el tratamiento episódico de la violencia intragénero y esa desconexión entre la esfera periodística y la de las organizaciones pudiera hacer prever una representación de las identidades gays a partir de prejuicios y estereotipos en la medida en que el varón homosexual pudiera ser abordado como el "otro" diferente (Israel, 2006; Coll-Planas, 2010), la presunción de que la cobertura quedaría dominada por aspectos eufemísticos y estereotipados tan solo se confirmaría parcialmente, pues estos no aparecen más que en una de cada cuatro piezas, lo cual revela que el discurso periodístico ha alcanzado un elevado grado de naturalidad a la hora de informar sobre la realidad de las relaciones gays. Así, si investigaciones anteriores (Carratalá, 2011a) habían demostrado que los eufemismos eran una estrategia útil en casos en los que el periodismo había de lidiar con el drama y la muerte en informaciones relacionadas con varones gays, los casos examinados señalan que la normalización de lo que se incorpora como natural en la agenda pública favorece una representación periodística más precisa y libre de prejuicios y ruidos interculturales. No obstante, los elementos de este tipo todavía presentes evidencian que algunas imágenes comúnmente aceptadas sobre la comunidad LGTB continúan siendo, en ocasiones, reforzadas por el discurso mediático, según comprobamos en algunos ejemplos en los que no reconocemos el ejercicio de un periodismo intercultural que derribe barreras entre un "nosotros" heterosexual y un "ellos" homosexual.

En conclusión, los resultados expuestos en el estudio confirman mayoritariamente la hipótesis de partida, que indicaba que la información periodística sobre la violencia en parejas del mismo sexo abordaría el fenómeno mediante estrategias similares a las que caracterizaron la cobertura de la violencia de género hasta que la sociedad la asumió como un problema de todos. En este caso, la información sobre los hechos sigue evidenciando un enfoque básicamente episódico propio de la crónica de sucesos, lo que se pone de manifiesto atendiendo a las fuentes mayoritariamente empleadas (entorno próximo, policía...), las imágenes reproducidas (rostro de la víctima, levantamiento del cadáver, lugar del crimen...), categorización de los hechos (crimen pasional), acento en el móvil del crimen (celos, delirio, drogas...), aspectos sensacionalistas (detalles escabrosos, circunstancias impactantes, infografía del crimen...) y a la culpabilización de la víctima -a quien se llega incluso a denominar como "amor fatal" del asesino ( $L R, 27 / 07 / 2011)$ - que se desprende del empleo de diversas estrategias narrativas (flirteaba con otros, no complació 
sexualmente al homicida, fue poco cuidadoso al iniciar una nueva relación tras la ruptura con el agresor, participó en -si no motivó- la discusión previa, había amenazado al homicida...).

El tratamiento primordialmente episódico del fenómeno de la violencia intragénero explica que la tematización de estos hechos sea muy escasa, así como la confusión sobre el modo en que deben ser categorizados e interpretados. El hecho de que algunas muestras de la cobertura equiparen esta realidad con la violencia de género -y todavía más que lo presenten como violencia domésticasugiere cierto interés desde la profesión periodística por construir un relato más explicativo sobre los hechos, que se aleje de lo particular para abordarlo como un problema de mayor calado. La ausencia de fuentes expertas y vinculadas a las organizaciones de defensa de los derechos de la comunidad LGTB en las informaciones examinadas ahonda en las carencias explicativas y dificulta todavía más una interpretación precisa de esta realidad, que parece no haber superado aún las primeras fases que cualquier asunto debe atravesar hasta quedar legitimado como problema que merece la consideración de toda la sociedad.

\section{Bibliografía}

Aldarte (s.f.): Ver, evaluar, actuar: la violencia en las relaciones lésbicas y homosexuales. Folleto.

Bardin, L. (1986): El análisis de contenido. Torrejón de Ardoz: Akal.

Berelson, B. R. (1971): Content Analysis in Communication Research. New York: Hafner.

Berganza, R. (2003): "La construcción mediática de la violencia contra las mujeres desde la Teoría del Enfoque". Comunicación y Sociedad, 16(2). Recuperado de:

http://www.unav.es/fcom/communication-society/es/articulo.php?art_id=97

Bosch Fiol, E. \& Ferrer Pérez, V.A. (2000): “La violencia de género: de cuestión privada a problema social”. Intervención psicosocial, 9(1), 7-19.

Carballido González, P. (2007): "Movimientos sociales y medios de comunicación: el cambio en el tratamiento de la violencia contra las mujeres". Recerca: revista de pensament i anàlisi, 7, 211-240.

Carratalá, A. (2011a): "La relación eufemística de la relación gay en el periodismo serio". Miguel Hernández Communication Journal, 2, 155-172. Recuperado de:

http://www.mhcj.es/mhcj/article/view/36/67

Carratalá, A. (2011b): “¿Smail o Cristina? Desigualdad e identidad transexual en el discurso periodístico". Zer: revista de estudios de comunicación, 16(31), 183-201.

Colectivo Lambda (2011): Informe sobre la situación de la violencia entre parejas del mismo sexo. http://www.felgtb.org/rs/4342/d112d6ad-54ec-438b-9358-4483f9e98868/8b2/fd/1/filename/informe2011-sobre-violencia-intragenero.pdf

Coll-Planas, G. (2010): La voluntad y el deseo. La construcción social del género y la sexualidad: el caso de lesbianas, gays y trans. Barcelona: Egales.

Coll-Planas, G. et al. (2008): "Cuestiones sin resolver en la Ley integral de medidas contra la violencia de género”. Papers, 87, 187-204. 
De Jong, M. J. W. (2006): "From invisibility to subversion”. En Castañeda, L. \& Campbell, S. (Eds.), News and sexuality. Media portraits of diversity (37-51). Thousand Oaks: Sage Publications.

Deacon, D. et al. (1999): Researching Communications: A Practical Guide to Methods in Media and Cultural Analysis. London: Hodder Arnold.

Downs, A. (1972): "Up and down with ecology: The issue attention cycle". Public interest, 28(1), 38-50.

Entman, R. M. (2007): "Framing Bias: Media in the Distribution of Power". Journal of Communication, 57, 163-173.

Fagoaga, C. (1994): “Comunicando violencia contra las mujeres”. Estudios sobre el mensaje periodístico, 1, 67-90.

Gámez Fuentes M. J. (2012): "Sobre los modos de visibilización mediático-política de la violencia de género en España: consideraciones críticas para su reformulación". OBETS. Revista de Ciencias Sociales, 7(2), 185-213.

Gámez Fuentes M. J. \& Núñez Puente, S. (2013): “Medios, ética y violencia de género: más allá de la victimización". Asparkía, 24, 145-160.

Gimeno, B. (2008): La construcción de la lesbiana perversa. Barcelona: Gedisa.

Gómez Nicolau, E. (2012): "Los marcos de interpretación de la violencia de género en las televisiones del Estado español. Modelos y tendencias". Cuestiones de género: de la igualdad y la diferencia, 7, 45-62.

Gomis, Ll. (1991): Teoría del periodismo: cómo se forma el presente. Barcelona: Paidós.

Hansen, A. et al. (1998): Mass Communication Research Methods. Basingstoke: Macmillan Press.

Hilgartner, S. \& Bosk, C. L. (1988): "The Rise and Fall of Social Problems: A Public Arenas Model”. American Journal of Sociology, 94(1), 53-78.

Israel, E. (2000): "Bases para el periodismo intercultural". Revista Latina de Comunicación Social, 34. Recuperado de: http://www.ull.es/publicaciones/latina/aa2000kj1/w34oc/43estrella.htm

Israel, E. (2006): Comunic@ ción y periodismo en una sociedad global: comunicar la diferencia. Sevilla: Editorial Trillas.

Marín, F. et al. (2011): "El tratamiento informativo de las víctimas de violencia de género en Euskadi: Deia, El Correo, El País y Gara (2002-2009)”. Comunicación y Sociedad, 24(1), 435-466.

Marugán Pintos, B. (2012): "Domesticar la violencia contra las mujeres, una forma de desactivar el conflicto intergéneros". Investigaciones feministas, 3, 155-166.

Meil Landwerlin, G. (2004): “Cambio familiar y maltrato conyugal hacia la mujer”. Revista Internacional de Sociología, 37, 7-27.

Menéndez Menéndez, M. I. (2014): "Retos periodísticos ante la violencia de género. El caso de la prensa local en España”. Comunicación y Sociedad, 22, 53-77.

Neveu, E. (2004): Sociologie du journalisme. Paris: Editions de La Découverte. 
Lippmann, W. (2003): Opinión pública. Madrid: Langre.

Reina Giménez, E. (2010): “¿Existe violencia en las parejas del mismo sexo? Buenas prácticas en la intervención en violencia en parejas del mismo sexo". TS nova: trabajo social y servicios sociales, 2 , 27-38.

Rodrigo Alsina, M. (2000): Identitats i comunicació intercultural. Valencia: Edicions 3i4.

Rodríguez Cárcela, R. (2008): "Del crimen pasional a la violencia de género: evolución y su tratamiento periodístico". Ámbitos, 17, 171-188.

Sampedro Blanco, V. (2008): “La jerarquía de las identidades mediáticas”. En Pérez-Amat, R. et al. (Eds.), Comunicación, identidad y género (39-51). Madrid: Fragua.

Taibi, M. (2003): "Hacia un discurso mediático por la convivencia y la tolerancia”. En Valero, C. \& Mancho, G. (Eds.), Discursos [dis]con/cordantes: Modos y formas de comunicación y convivencia (35-58). Alcalá de Henares: Servicio de Publicaciones de la Universidad de Alcalá.

Van Dijk, T. A. (2008): “Semántica del discurso e ideología”. Discurso \& Sociedad, 2(1), 201-261.

Vreese, C. H. de (2005): "News Framing: Theory and typology". Information Design Journal + Document Design, 13 (1), 51-62.

Vives-Cases, C. et al. (2005): "Historia reciente de la cobertura periodística de la violencia contra las mujeres en el contexto español (1997-2001)”. Gaceta Sanitaria, 19(1), 22-28.

Zurbano Berenger, B. (2012): “El concepto 'violencia de género' en la prensa diaria nacional española”. Cuestiones de género: de la igualdad y la diferencia, 7, 25-44.

Zurbano Berenguer, B. (2010a): "El uso del concepto 'violencia de género' en la prensa diaria de tirada nacional en España”. En Actas - II Congreso Internacional Latina de Comunicación Social. Universidad La Laguna. Recuperado de:

http://www.academia.edu/562809/El_uso_del_concepto_violencia_de_g\%C3\%A9neroen_la_prensa _diaria_de tirada_nacional_en_Espa\%C3\%B1a

Zurbano Berenguer, B. (2010b): "Más allá del crimen y el suceso: la violencia de género en la prensa española". En Mancinas Chávez, R. \& Nogales Bocio, A. (Eds.), La mujer en el espejo mediático. El mediotrato femenino (93-102). Sevilla: Asociación Universitaria Comunicación y Cultura (AUCC).

\section{Cómo citar este artículo / Referencia normalizada}

A Carratalá (2016): "La información en prensa española sobre casos de violencia en parejas del mismo sexo". Revista Latina de Comunicación Social, 71, pp. 40 a 65.

http://www.revistalatinacs.org/071/paper/1083/03es.html

DOI: $\underline{10.4185 / R L C S-2016-1083}$

- En el interior de un texto:

... A Carratalá (2016: 40-65)...

Artículo recibido el 14 de noviembre de 2015. Aceptado el 29 de diciembre. Publicado el 15 de enero de 2016 